Alanine dephenylhydantoin free fatty acids glucagon \section{gluconeogenesis \\ Reduced Gluconeogenesis due to Hyperinsulinism: Hormonal and Metabolic Studies in an Infant with Hypoglycemia}

\author{
JOSTEIN VIDNES ${ }^{(49)}$ AND STEPHANIE ÖYASAITER
}

Pediatric Research Institute, Rikshospitalet, University Hospital, Oslo, Norway hypoglycemia

insulin

lipolysis

pyruvate

triglycerides

\section{Summary}

An infant with a family history of hypoglycemia suffered from severe hypoglycemia caused by hyperinsulinism. Glucagon secretion was normal. The in vivo incorporation of ${ }^{14} \mathrm{C}$ from alanine into glucose was much reduced, but the key gluconeogenic enzymes revealed normal to high activities in vitro, with normal intracellular distributions. The glucogenic amino acids in plasma tended to be high, especially proline. An alanine load revealed a normal glucagon secretion pattern, whereas the insulin secretion was inappropriately strong. The insulin response to glucagon, however, was subnormal. The alanine load caused a paradoxic drop in plasma pyruvate. Serial determinations of the fasting values of plasma alanine and free fatty acids (FFA) disclosed a highly significant negative correlation.

The best therapeutic effect was obtained with long acting glucagon sc twice daily, but hypoglycemia before the next injection of glucagon could not be avoided. Glucagon treatment caused a marked drop in the plasma amino acids, including the branched-chained, and a highly significant decrease in plasma triglycerides and increase in FFA, whereas glycerol did not change. Diphenylhydantoin caused a significant increase in blood glucose, but therapeutic serum levels of the drug were difficult to achieve.

During glucagon treatment an oral glucose tolerance test was normal, with a normal increase in insulin, whereas an iv glucose tolerance test was diabetic $\left(K_{G}=1.0\right)$, and there was no rise in insulin.

It is concluded that the reduced in vivo incorporation of ${ }^{14} \mathrm{C}$ into glucose from alanine reflected a reduced gluconeogenesis, and it is proposed that the reduced gluconeogenesis is a main contributor to hypoglycemia in hyperinsulinism.

\section{Speculation}

In most in vivo systems changes in insulin concentrations are associated with changes in glucagon, making it difficult to discern the pure effects of insulin. In the presented patient a normal glucagon secretion was faced with an inappropriately high insulin secretion, providing information about pure insulin effects.

Hyperinsulinism is the most common cause of recurrent hypoglycemia in infants under 1 year of age (35). It is generally acknowledged that this hypoglycemia is caused by increased peripheral glucose utilization combined with a decreased hepatic glucose production. The suppressive effect of insulin on hepatic glycogenolysis is well known $(1,17)$. An inhibitory action on gluconeogenesis is also well established in animals $(5,14,25)$. Insulin deficiency in animals and man is associated with an increased gluconeogenesis, which is normalized by insulin treatment $(9,41)$. The effect of insulin hypersecretion on gluconeo- genesis in vivo in man, however, is still a matter of controversy $(5,11)$. This paper presents evidence for a much reduced gluconeogenesis in an infant with hyperinsulinism. The hypoglycemia was best counteracted by injections of long acting glucagon.

\section{CASE REPORT}

BRB, a boy, was born at term on February 16, 1975, after a normal pregnancy. Birthweight was $2800 \mathrm{~g}$, length $48 \mathrm{~cm}$, and the neonatal period was uneventful. The patient has two sisters, one of whom suffered from hypoglycemia from the age of 2 months. Furthermore, both the mother and the mother's mother had suffered from hypoglycemia. The sister and the mother recovered spontaneously at 4-5 years of age, and are now in good health, except that the sister is slightly mentally retarded. Studies of the other family members were refused.

The patient first experienced symptoms of hypoglycemia at 4.5 months of age, when he got attacks with loss of tonus, eyerolling, smacking of the lips, and, occasionally, convulsions. He was first admitted to our hospital at 7 months of age, with a blood glucose value of $0.83 \mathrm{mmol} /$ liter. Routine laboratory investigations were normal, except for moderate elevations of alanine aminotransferase and aspartate aminotransferase in serum. These values later normalized, but intermittently alanine aminotransferase, alkaline phosphatase, and $\gamma$-glutamyl transpeptidase were elevated. The liver was not enlarged, and appeared normal by laparotomy for liver biopsy. Histologically, there was abundant cytoplasmic glycogen, unevenly distributed; otherwise the liver was normal. EEG was normal.

Inappropriately high fasting insulin values compared with the blood glucose values were found (Table 2) (35) and the insulin response to alanine was abnormally strong (Fig. 2). The hypoglycemia was consequently judged to be caused by hypersecretion of insulin. The disorder was difficult to treat. Diphenylhydantoin caused a significant rise in the mean glucose values, but the patient was still hypoglycemic (Table 1). The most effective increase in blood glucose was achieved with zinc protamine glucagon, $0.1 \mathrm{mg} / \mathrm{kg}$ body wt sc twice daily (Table 1, Fig. 1). However, asymptomatic hypoglycemia was registered the last few hours before the next injection of glucagon (Fig. 1). This drop in blood glucose could not be overcome, either by increasing the frequency of injections, or by increasing the dose of glucagon. The increased blood glucose values were reflected in a reduced frequency of symptomatic hypoglycemic attacks, and the mental and motor development improved. On discharge the condition was fairly well controlled by supplemental glucose, diphenylhydantoin, and zinc protamine glucagon.

At 2 years of age the mental and motor development was moderately retarded. Physically, the patient was small ( 2.5 percentile), but with normal proportions. The bone age was slightly retarded, and the face appeared round and moon shaped. 
Table 1. Effect of diphenylhydantoin and zinc protamine glucagon on mean blood glucose values'

\begin{tabular}{lcc}
\hline & \multicolumn{2}{c}{ Diphenylhydantoin $^{2}$} \\
\cline { 2 - 3 } & $<20 \mu \mathrm{mol} /$ liter & $>20 \mu \mathrm{mol} /$ liter \\
\hline $\begin{array}{c}\text { Blood glucose, } \\
\mathrm{mmol} / \text { liter }\end{array}$ & $1.78 \pm 0.05(45)^{3}$ & $2.02 \pm 0.09(28)$ \\
& \multicolumn{2}{c}{$P<0.02$} \\
\hline
\end{tabular}

Zinc protamine glucagon ${ }^{2}$

Blood glucose,

\begin{tabular}{ll}
\hline Before treatment & During treatment \\
\hline $1.86 \pm 0.04(78)$ & $2.63 \pm 0.16(32)$
\end{tabular}
$\mathrm{mmol} / \mathrm{liter}$

$$
P<0.0001
$$

1 Blood glucose is presented as the mean of the average blood glucose values during 24-hr periods ( $\pm 1 \mathrm{SE}$ )

${ }^{2}$ Diphenylhydantoin was administered perorally, zinc protamine glucagon was injected sc twice daily.

${ }^{3}$ Number of registration periods.

\section{MATERIALS AND METHODS}

All investigations, in the patient as well as in the control subjects, were performed with the parents' consent. The ethical aspects of isotope studies have been discussed in a previous publication (37).

$\mathrm{L}-\left[U-{ }^{14} \mathrm{C}\right]$ alanine and $\left[{ }^{14} \mathrm{C}\right]$ bicarbonate were purchased from the Radiochemical Centre, Amersham. Enzymes were obtained from Sigma Chemical Company. Zinc protamine glucagon was purchased from Novo Industri A/S, Denmark, and diphenylhydantoin (Epinat) from Nyegaard \& Co., Oslo.

Plasma was obtained from heparinized venous blood immediately put into an ice bath and separated at $4^{\circ}$. Trasylol was added to blood intended for glucagon analysis. Blood glucose was determined by the ortho-toluidine method (18), plasma alanine and pyruvate were analyzed microfluorometrically (19), and FFA, glycerol, and plasma triglycerides according to the "Biochemica Test Combination" (Boehringer, Mannheim, West Germany).

Amino acids in plasma were determined with a conventional ion exchange procedure at the Department of Clinical Chemistry, Rikshospitalet, Oslo, and diphenylhydantoin in serum by gas-liquid chromatography at the National Epilepsy Centre, Sandvika, Norway.

The alanine tolerance test was performed by injecting $0.25 \mathrm{~g}$ $\mathrm{L}$-alanine/ $\mathrm{kg}$ body wt iv for $1-2 \mathrm{~min}$ as a $10 \%$ solution. The results were compared with the results of the same test performed in six patients (from 7 months to 3.5 years of age) with hypoglycemia, in whom disorders of insulin and glucagon secretion had been excluded.

The standard glucagon tolerance test was performed by injecting $0.02 \mathrm{mg}$ short acting glucagon/ $\mathrm{kg}$ body wt rapidly iv, the oral glucose tolerance test by giving $1.75 \mathrm{~g}, 2 \mathrm{~g}$, or $2.5 \mathrm{~g}$ glucose/ $\mathrm{kg}$, and the iv glucose tolerance test by injection of $0.5 \mathrm{~g}$ glucose $/ \mathrm{kg}$. The tests were done in the morning and the fasting periods were $6-8 \mathrm{hr}$, according to the patient's tolerance of fasting.

\section{ANALYSES OF HORMONES}

Plasma immunoreactive pancreatic glucagon was determined in triplicate according to the method of Heding (16) with the pancreas glucagon specific antiserum K 964 from Novo Research Institute, Denmark, which also supplied us with glucagon for standards and $\left[{ }^{125} \mathrm{I}\right]$ glucagon. Nonspecific plasma interference with the assay was tested for as described by Weir (42). Immunoreactive insulin was determined by the double antibody method (15) with kits from the Radiochemical Centre, Amersham. 17-Hydroxycorticosteroids and growth hormone were determined at the Division of Endocrinology, Medical Department B, and thyroxin at the Department of Clinical Chemistry, Rikshospitalet, Oslo.

\section{ASSAY OF GLUCONEOGENESIS}

The in vivo method employed is based upon the appearance of radioactivity in glucose after iv injection of trace amounts of $\left[{ }^{14} \mathrm{C}\right]$ alanine $(5 \mu \mathrm{Ci} / \mathrm{kg}$ body wt). Plasma was analyzed for the amount of radioactivity in alanine, lactate, and glucose by thin layer chromatography. The results are presented as percentages of the total amount of $\left[{ }^{14} \mathrm{C}\right]$ alanine injected, taking different distribution volumes into account. The appearance of $\left[{ }^{14} \mathrm{C}\right]$ glucose was used as an index of the overall in vivo gluconeogenesis. The results in four normoglycemic patients used as control subjects and details of the method have been published previously (37).

The four key enzymes of gluconeogenesis were analyzed in a liver specimen obtained by an open liver biopsy. The liver was immediately frozen and stored in liquid $\mathrm{N}_{2}$. Before the biopsy the patient had been fasted for $8 \mathrm{hr}$, but during the operation he received $5 \%$ glucose as a continuous iv drip. The human control specimen was obtained from the liver of a 2-year-old boy operated on for a hepatoma. Livers from Wistar rats weighing from 55 to $173 \mathrm{~g}$ were also used as controls. Glucose-6-phosphatase, fructose-1,6-diphosphatase, phosphoenolpyruvate carboxykinase (PEPCK), pyruvate carboxylase (PC), and glutamic dehydrogenase $(\mathrm{GDH})$ were assayed as previously described (39). GDH was assayed as a mitochondrial marker. For correction of mitochondrial leakage the following formula was used: $E_{c}=\left[\left(E_{u}-L\right) /(100-L)\right] \cdot 100 \%$, where $E_{c}=$ corrected extramitochondrial activity in percentage, $E_{u}=$ uncorrected extramitochondrial activity in percentage, and $\mathrm{L}=$ percentage of mitochondrial leakage as determined by the GDH determinations.

\section{STATISTICS}

The level of significance was calculated using Student's $t$-test for two means, or the paired $t$-test, as judged appropriate. A $P$ value of 0.05 was chosen as the significance level. The $K$ value for glucose disappearance rate was calculated as described previously (38). Linear regression was calculated by the method of least squares.

\section{RESULTS}

\section{SECRETION OF HORMONES}

Table 2 reveals too high fasting insulin values compared with simultaneously obtained blood glucose values, whereas plasma

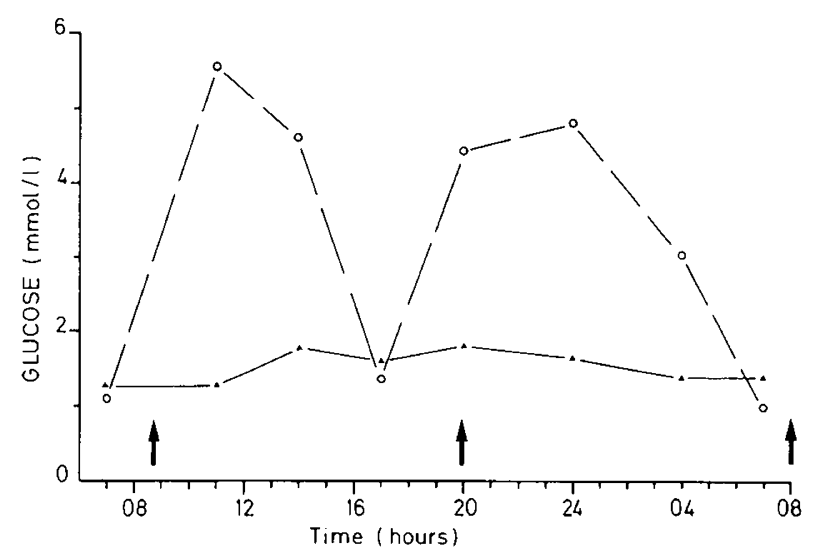

Fig. 1. Blood glucose values during the 24-hr period before glucagon treatment was started $(\mathbf{\Delta}-\mathbf{\Lambda})$, and a typical 24-hr curve during treatment $\left(\mathrm{O}_{-}-\mathrm{O}\right)$. Black arrows indicate the injection of long acting glucagon. 
Table 2. Fasting values of insulin, glucagon, and some main metabolites ${ }^{1}$

\begin{tabular}{lccc}
\hline \multicolumn{1}{c}{ Hormones and metabolites } & Before glucagon treatment & During glucagon treatment & $P$ values $^{2}$ \\
\hline Glucose $(\mathrm{mmol} / \mathrm{liter})$ & $1.40 \pm 0.11(9)^{3}$ & $1.73 \pm 0.09(5)$ & $0.10>P>0.05$ \\
Insulin $(\mu \mathrm{U} / \mathrm{ml})$ & $24 \pm 3.0(9)$ & $30 \pm 9.1(5)$ & NS $^{4}$ \\
Glucagon $(\mathrm{pg} / \mathrm{ml})^{5}$ & $76 \pm 8.5(4)$ & $176 \pm 26.8(5)$ & $<0.02$ \\
Alanine $(\mu \mathrm{mol} / \mathrm{liter})$ & $292 \pm 24.8(9)$ & $23 \pm 5.9(4)$ & $\mathrm{NS}$ \\
Pyruvate $(\mu \mathrm{mol} / \mathrm{liter})$ & $33 \pm 4.9(9)$ & $0.74 \pm 0.08(6)$ & $<0.005$ \\
Triglycerides $(\mathrm{mmol} / \mathrm{liter})$ & $1.12 \pm 0.08(7)$ & $1.33 \pm 0.20(6)$ & $<0.005$ \\
FFA (mmol/liter) & $0.57 \pm 0.08(7)$ & $0.21 \pm 0.03(4)$ & $\mathrm{NS}$ \\
Glycerol $(\mathrm{mmol} / \mathrm{liter})$ & $0.21 \pm 0.04(6)$ & &
\end{tabular}

1 The values are given as mean $\pm \mathrm{SE}$.

${ }^{2}$ The level of significance was calculated by means of the unpaired Student's $t$-test.

${ }^{3}$ Numbers of samples in parentheses.

${ }^{4}$ Not significant.

5 The nonspecific plasma interference of about $24 \mathrm{pg} / \mathrm{ml}$ not subtracted.

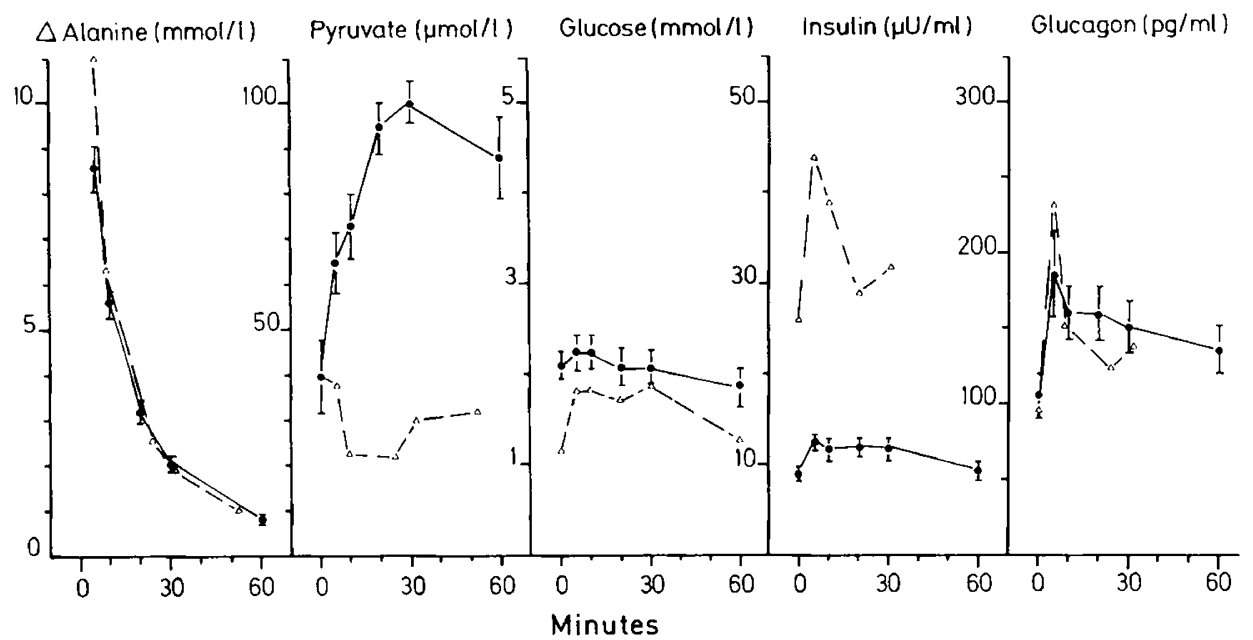

Fig. 2. Changes in plasma alanine, pyruvate, glucose, insulin, and glucagon after the rapid infusion of alanine at zero time. For alanine the increase above baseline values is given ( $\Delta$ alanine), whereas the absolute values are given for the other parameters. The patient is compared with six hypoglycemic control subjects (mean $\pm \mathrm{SE}$ ).

glucagon concentrations were normal (35). The alanine tolerance test also indicated insulin hypersecretion (Fig. 2), with an inappropriately high basal insulin value, and an inordinately strong insulin response to stimulation with alanine. Glucagon secretion however, was similar to that of the controls, as was both the increase in plasma alanine and the subsequent disappearance rate. In all the controls, pyruvate increased 2-3 times during the alanine tolerance test. In contrast, blood pyruvate in the patient decreased sharply. Blood glucose increased during the test (Fig. 2).

The oral glucose tolerance test was performed twice before glucagon treatment was started, with $1.75 \mathrm{~g}$ and $2.5 \mathrm{~g}$ glucose/ $\mathrm{kg}$ body wt. On both occasions the rise in blood glucose was subnormal, from basal levels of 0.78 and $1.0 \mathrm{mmol} / \mathrm{liter}$ to maxima of 1.11 and $2.0 \mathrm{mmol} /$ liter after $30 \mathrm{~min}$, respectively. Insulin was not measured during these tests. During a glucagon tolerance test blood glucose increased from 1.2 to $3.6 \mathrm{mmol} /$ liter after $20 \mathrm{~min}$, and insulin rose from 18 to $25 \mu \mathrm{U} / \mathrm{ml}$ after 10 min.

During glucagon treatment glucose tolerance tests were performed in the morning before the next injection of glucagon. A load of $2.0 \mathrm{~g}$ glucose $/ \mathrm{kg}$ body wt perorally caused a rise in blood glucose from $1.7 \mathrm{mmol} /$ liter to a maximum of $4.5 \mathrm{mmol} / \mathrm{liter}$ at 30 and $60 \mathrm{~min}$, and insulin rose from $54 \mu \mathrm{U} / \mathrm{ml}$ to $104 \mu \mathrm{U} / \mathrm{ml}$ after $60 \mathrm{~min}$. In contrast with the oral glucose tolerance test the iv glucose tolerance test appeared diabetic. Blood glucose increased from 1.8 to $8.6 \mathrm{mmol} / \mathrm{liter}$. The subsequent disappearance rate was slow $\left(\mathrm{K}_{\mathrm{G}}=1.0 \% / \mathrm{min}\right)$, and there was essentially no rise in plasma insulin level, which oscillated between 31 and $35 \mu \mathrm{U} / \mathrm{ml}$.
17-OH-corticosteroids in urine and plasma were normal, as was growth hormone in plasma. Serum thyroxin was low normal.

\section{STUDIES OF GLUCONEOGENESIS}

The in vivo study with $\left[{ }^{14} \mathrm{C}\right]$ alanine disclosed a severely reduced incorporation of ${ }^{14} \mathrm{C}$ into glucose (Fig. 3). Nevertheless, the disappearance rate of ${ }^{14} \mathrm{C}$ from alanine was barely reduced, and the appearance of ${ }^{14} \mathrm{C}$ in lactate was similar to that of the control subjects. Mean blood glucose during the study was 1.3 $\mathrm{mmol} /$ liter, plasma alanine $365 \mu \mathrm{mol} / \mathrm{liter}$, pyruvate $25 \mu \mathrm{mol} /$ liter, and insulin $28 \mu \mathrm{U} / \mathrm{ml}$. These concentrations changed minimally during the study.

Since the $\left[{ }^{14} \mathrm{C}\right]$ alanine test pointed to a severely reduced gluconeogenesis, the key gluconeogenic liver enzymes were studied. In none were the activities reduced (Tables 3 and 4). On the contrary, the activity of PEPCK was high (Table 4). The intracellular distribution was normal.

However, the reduced gluconeogenesis was reflected in the glucogenic amino acids, which were generally elevated, especially glutamine and proline (Table 5). It is of interest to note that serial determinations of the fasting values of alanine were negatively correlated with the FFA values. The correlation was highly significant $(r=-0.84, n=12, P<0.001)$.

\section{EFFECTS OF TREATMENT}

Diphenylhydantoin has been shown to depress insulin and stimulate glucagon secretion in the golden hamster (36), and in man hyperinsulinism has been reported to be successfully treated with diphenylhydantoin when other drugs have failed (3). In our 


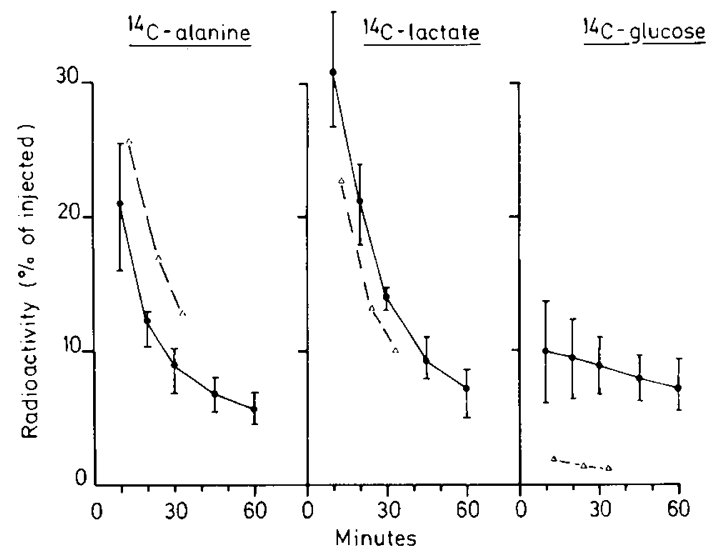

Fig. 3. Time course for the incorporation of ${ }^{14} \mathrm{C}$ from labeled alanine into plasma lactate and glucose. A tracer dose was rapidly injected iv at zero time. The values are presented as percentages of the injected radioactivity, and are compared with the mean values of four normoglycemic patients, the vertical bars showing the range. The patient was studied before any drug treatment was started.

Table 3. Activities of glucose-6-phosphatase and fructose-1,6diphosphatase in liver

\begin{tabular}{lcc}
\hline & $\begin{array}{c}\text { Glucose-6- } \\
\text { phosphatase, } \\
\mu \mathrm{mol} / \mathrm{min} / \mathrm{g}^{1}\end{array}$ & $\begin{array}{c}\text { Fructose-1,6- } \\
\text { diphosphatase, } \\
\mu \mathrm{mol} / \mathrm{min} / \mathrm{g}\end{array}$ \\
\hline Patient & 20.9 & 12.7 \\
Rats, fed (6) $)^{2}$ & 21.3 & 20.2 \\
Rat, fasted (1) & & 33.3 \\
\hline
\end{tabular}

1 The enzyme activities are presented as micromoles of phosphate liberated per min per g liver.

${ }^{2}$ The corresponding activities in rat livers are presented for comparison. Numbers of animals in parentheses.

Table 4. Activities of PEPCK and PC in liver

\begin{tabular}{|c|c|c|c|c|}
\hline & \multicolumn{2}{|c|}{ PEPCK } & \multicolumn{2}{|c|}{ GDH } \\
\hline & $\begin{array}{c}\text { Total } \\
\text { activity, } \\
\mathrm{U} / \mathrm{g}^{1}\end{array}$ & $\begin{array}{c}\text { Extra- } \\
\text { mito- } \\
\text { chondrial, } \\
\%^{2}\end{array}$ & $\begin{array}{c}\text { Total } \\
\text { activity, } \\
\mathrm{U} / \mathrm{g}^{3}\end{array}$ & $\begin{array}{c}\text { Extra- } \\
\text { mito- } \\
\text { chondrial } \\
\text { ("leakage"), } \\
\%\end{array}$ \\
\hline Patient & 17.2 & 35 & 3010 & 32.8 \\
\hline Human control & 6.0 & 35 & 1626 & 48.5 \\
\hline Rats, fed $(8)^{4}$ & 2.6 & 85 & 2023 & 23.2 \\
\hline \multirow[t]{3}{*}{ Rats, fasted (6) } & 6.1 & 89 & 2777 & 15.8 \\
\hline & \multicolumn{2}{|c|}{$\mathrm{PC}$} & \multicolumn{2}{|c|}{$\mathrm{GPH}$} \\
\hline & $\begin{array}{c}\text { Total } \\
\text { activity, } \\
\mathrm{U} / \mathrm{g}^{1}\end{array}$ & $\begin{array}{c}\text { Extra- } \\
\text { mito- } \\
\text { chondrial, } \\
\%^{2}\end{array}$ & $\begin{array}{c}\text { Total } \\
\text { activity, } \\
\mathrm{U} / \mathrm{g}^{3}\end{array}$ & $\begin{array}{c}\text { Extra- } \\
\text { mito- } \\
\text { chondrial } \\
\text { ("leakage"), } \\
\%\end{array}$ \\
\hline Patient & 7.0 & 8 & 3010 & 32.8 \\
\hline Human control & 7.1 & 4 & 1588 & 39.0 \\
\hline Rats, fed $(7)^{4}$ & 10.1 & 2 & 1997 & 23.0 \\
\hline Rats, fasted (6) & 14.0 & 2 & 2330 & 22.3 \\
\hline
\end{tabular}

${ }^{1}$ One unit per $\mathrm{g}$ was defined as $1 \mu \mathrm{mol}$ bicarbonate incorporated per min per $g$ liver at $37^{\circ}$.

2 The percentages have been corrected for extramitochondrial leakage as mentioned in the text.

${ }^{3}$ One unit per $\mathrm{g}$ corresponds to the reduction of $1.09 \mu \mathrm{mol} \mathrm{NADH} /$ $\mathrm{hr} / \mathrm{g}$ liver at $25^{\circ}(31)$.

${ }^{4}$ Numbers of animals in parentheses.
Table 5. Amino acids in plasma

\begin{tabular}{|c|c|c|c|c|}
\hline Amino acids & $\begin{array}{l}\text { Normal values } \\
\text { mean (range), } \\
\mu \mathrm{mol} / \text { liter }^{1}\end{array}$ & $\begin{array}{c}\begin{array}{c}\text { Before } \\
\text { glucagon }\end{array} \\
\text { treatment, } \\
\mu \text { mol/liter }\end{array}$ & $\begin{array}{c}\text { During } \\
\text { glucagon } \\
\text { treatment, } \\
\mu \text { mol/liter }\end{array}$ & $\begin{array}{c}\% \\
\text { Change }^{2}, \\
\mu \text { mol/liter }\end{array}$ \\
\hline Aspartate & $2(0-9)$ & 3 & 3 & 0 \\
\hline Threonine & $60(33-128)$ & 147 & 67 & -54 \\
\hline Serine & $92(24-172)$ & 105 & 93 & -11 \\
\hline Asparagine & $44-70^{3}$ & 61 & 51 & -16 \\
\hline Glutamate & $11-37^{3}$ & 46 & 28 & -39 \\
\hline Glutamine & $576-718^{3}$ & 713 & 325 & -54 \\
\hline Proline & $115(51-185)$ & 303 & 85 & -72 \\
\hline Glycine & $170(56-308)$ & 227 & 149 & -34 \\
\hline Alanine & $219(99-313)$ & 262 & 195 & -26 \\
\hline$\alpha$-Aminobutyrate & $5(0-17)$ & 11 & 3 & -73 \\
\hline Valine & $127(57-262)$ & 177 & 121 & -32 \\
\hline Cystine & $38-58^{3}$ & 81 & 44 & -46 \\
\hline Methionine & $21(3-29)$ & 19 & 25 & +32 \\
\hline Isoleucine & $44(26-94)$ & 48 & 24 & -50 \\
\hline Leucine & $75(45-155)$ & 94 & 49 & -48 \\
\hline Tyrosine & $45(11-122)$ & 62 & 39 & -37 \\
\hline Phenylalanine & $40(23-69)$ & 51 & 42 & -18 \\
\hline Ornithine & $40(10-107)$ & 55 & 17 & -69 \\
\hline Lysine & $87(45-144)$ & 86 & 97 & +13 \\
\hline Histidine & $64(24-112)$ & 86 & 87 & +1 \\
\hline Arginine & $31(11-65)$ & 52 & 29 & -44 \\
\hline
\end{tabular}

patient diphenylhydantoin resulted in a slight, but significant increase in blood glucose (Table 1). No effect on plasma insulin or glucagon values could be disclosed. However, it was difficult to obtain serum values of the drug in the therapeutic range (above $40 \mu \mathrm{mol} / \mathrm{liter}$ ), and the patient was still hypoglycemic.

Treatment with zinc protamine glucagon was tried. Figure 1 shows the blood glucose values during the 24-hr period before glucagon treatment was started, and a typical 24-hr curve during glucagon treatment. Except for glucagon, treatment was unchanged (diphenylhydantoin and extra glucose). The increase in the mean blood glucose values was highly significant (Table 1). In contrast to the mean glucose values, the rise caused by glucagon treatment in the low fasting glucose values was not statistically significant (Table 2). Fasting insulin, pyruvate, and glycerol were not changed. Plasma alanine fell significantly, but the most impressive changes were observed in the concentrations of triglycerides and FFA; both the increase in FFA and the decrease in triglycerides were highly significant (Table 2).

Glucagon treatment caused an average reduction in the plasma amino acids of $40 \%$ (Table 5). The reduction in proline was most pronounced. The branched-chained amino acids were reduced to the same degree as the other amino acids.

\section{DISCUSSION}

An infant with hypoglycemia caused by hypersecretion of insulin has been described. The observed severe reduction of the in vivo incorporation of ${ }^{14} \mathrm{C}$ from alanine into glucose could result from diversion of label into glycogen, an increased utilization rate of glucose, an increased glucose space, or from a reduced rate of gluconeogenesis.

During acute administration of insulin the flow of substrates may be diverted from glucose synthesis into the synthesis of glycogen $(1,5,17)$. In the fasting steady state, however, a net synthesis of glycogen will not occur. Insulin administration to fasted animals in fact decreases the incorporation of label into glycogen from gluconeogenic precursors, and the amount of label in glycogen in animals and in man during fasting is minimal 
compared with the amount in glucose $(4,5,6,14)$. In addition, abundant liver glycogen and low blood glucose values, as observed in the patient described, inhibits glycogen synthesis $(9$, 17).

An increased utilization rate of glucose could not account for the reduced incorporation of ${ }^{14} \mathrm{C}$ into glucose, since the metabolic flow of label the first minutes after the single injection of a radioactive tracer is unidirectional. In the case of $\left[{ }^{14} \mathrm{C}\right] \mathrm{alanine}$, the appearance of label in glucose the first 5-10 min reflects mainly gluconeogenesis, whereas the later disappearance of label from glucose reflects mainly the utilization rate $(14,37)$ In the patient described the appearance of label in glucose was greatly reduced, whereas the disappearance rate paralleled that of the control subjects (Fig. 3). A change in glucose space could only account for a very minor part of the reduction. In addition, it has been doubted whether insulin really increases glucose space (47).

It is thus concluded that the reduced incorporation of ${ }^{14} \mathrm{C}$ into glucose reflected a reduced rate of gluconeogenesis. This reduction was coincident with elevated plasma insulin values, and we infer that the reduced gluconeogenesis was caused by hyperinsulinism, facing a normal secretion of glucagon. In a patient previously described by us, a severely reduced gluconeogenesis was associated with glucagon deficiency and normal insulin secretion (38).

The question is then: by which mechanism does insulin reduce gluconeogenesis? Alanine is mainly taken up and metabolized by the liver (10), and insulin might decrease the extraction and transamination of alanine (11). However, the close to normal kinetics of $\left[{ }^{14} \mathrm{C}\right]$ alanine and $\left[{ }^{14} \mathrm{C}\right]$ lactate do not support this hypothesis. More probably, the conversion of pyruvate to glucose within the liver was inhibited, but this inhibition was not reflected in the in vitro activities of the key gluconeogenic enzymes, which were normal, and the activity of PEPCK was elevated. Insulin has been shown to be able to inhibit PEPCK, but this requires the availability of carbohydrate (33, $45)$. The patient was severely glucose deficient, and hypoglycemia probably stimulates the activity of $\operatorname{PEPCK}(9,33)$.

The in vivo activity of the gluconeogenetic key enzymes might nevertheless be restricted. Insulin decreases the transport of pyruvate into the mitochondria, and of malate and aspartate out of the mitochondria $(6,9,25,26)$. In turn, the substrates available for PC and PEPCK are decreased and the rate of gluconeogenesis is slowed down. Another mechanism may be that insulin increases the activity of glycolytic enzymes, like pyruvate kinase, the inhibition of which a normally functioning gluconeogenesis is dependent upon. Otherwise, futile cycles are created with inhibition of gluconeogenesis and wastage of energy $(13,43,45)$.

Insulin decreases lipolysis, decreasing the supply of acetyl$\mathrm{CoA}$ and NADH derived from the breakdown of fat. A reduced level of acetyl-CoA and NADH increases the activity of the pyruvate dehydrogenase complex $(7,28)$, and may decrease the in vivo activity of $\mathrm{PC}$, for which enzyme acetyl-CoA is an allosteric activator $(24,28,40)$. The net result of the mechanisms mentioned is that pyruvate is used preferentially for oxidation and fatty acid synthesis rather than for gluconeogenesis.

The hyperglycemic action of glucagon faded the last hours before the next injection. We believe that the hyperglycemic action of glucagon mainly reflected increased glycogenolysis, although the effect of glucagon on glycogenolysis has been claimed to be evanescent, lasting for only 30-40 min during continuous infusions of glucagon $(12,32)$. An exhaustion of the liver glycogen stores would cause a drop in blood glucose. In addition, glucagon stimulates gluconeogenesis, in this patient reflected by the decreased glucogenic amino acids (9). In a patient with glucagon deficiency glucagon restored normoglycemia throughout the day (38).

The branched-chained amino acids are catabolized in muscle and other tissues outside the liver under the influence of insulin $(2,10)$. The decrease caused by glucagon treatment was therefore not expected, but may indicate that the peripheral catabolism of these amino acids depends on a normal function of the glucose-alanine cycle. This cycle, transporting amino groups to the liver, is disrupted when gluconeogenesis is impaired and restored by glucagon treatment (10).

The decreased triglycerides and increased FFA during glucagon treatment pointed to an important effect of glucagon. on lipolysis, thus providing extra energy-yielding substrates and sparing glucose $(20,22,28,30)$. Additionally, the highly significant inverse correlation between alanine and FFA might point to an essential role of FFA in stimulating gluconeogenesis $(14,28,44)$. Glycerol is mainly metabolized to glucose (37). The unchanged glycerol values during glucagon treatment might therefore reflect that an increased gluconeogenesis compensated for the increased lipolysis.

The insulin secretion response varied with different insulin secretagogues. The response to stimulation with alanine was excessive, the response to glucose per orally was normal, the response to glucagon was subnormal, and the response to glucose iv was virtually zero. This insulin secretion pattern was believed to be indicative of a disturbed pancreatic $B$ cell regulation (29).

The alanine tolerance test caused a paradoxic decrease in the pyruvate concentrations (Fig. 2). We observed a similar response in a patient with glucagon deficiency (38) (unpublished data). The insulin response in these patients was exaggerated or unopposed, causing decreased transamination of alanine, increased pyruvate decarboxylation, and perhaps increased disposal of alanine for protein synthesis $(2,9,10)$. Blood glucose increased in the patient with hyperinsulinism, but decreased in the patient with glucagon deficiency. This finding is consistent with the concept that the changes in blood glucose after an alanine load mainly reflects glucagon secretion (46).

The Mauriac syndrome is characterized by hepatomegaly with slightly disturbed liver function, dwarfism, moon-shaped face, and cushingoid fat deposition, and is probably caused by the inappropriate administration of short acting insulin in diabetes $(21,23)$. Some of these features were recognized in the presented patient. In addition, liver affection was observed in a child subjected to malicious insulin administration (8). We suggest that similar affections may be caused by endogenous hyperinsulinism.

Finally, we conclude that gluconeogenesis is severely reduced in hyperinsulinism, and we propose that the reduced gluconeogenesis is a main contributor to the hypoglycemia of this disorder.

\section{REFERENCES AND NOTES}

1. Bishop, J. S., Steele, R., Altszuler, N., Dunn, A., Bjerknes, C., and Bodo, R. C. de: Effects of insulin on liver glycogen synthesis and breakdown in the dog. Amer. J. Physiol., 208: 307 (1965).

2. Brockman, R. P., Bergman, E. N., Joo, P. K., and Manns, J. G.: Effects of glucagon and insulin on net hepatic metabolism of glucose precursors in sheep. Amer. J. Physiol., 229: 1344 (1975).

3. Brodows, R. G., and Campbell, R. G.: Control of refractory fasting hypoglycemia in a patient with suspected insulinoma with diphenylhydantoin. $y$. Clin. Endocrinol. Metab., 38: 159 (1974).

4. Chiasson, J. L Liljenquist, J. E., Sinclair-Smith, B. C., and Lacy, W. W. Gluconeogenesis from alanine in normal postabsorptive man. Intrahepatic stimulatory effect of glucagon. Diabetes, 24: 574 (1975).

5. Chiasson, J. L., Liljenquist, J. E., Finger, F. E., and Lacy, W. W.: Differential sensitivity of glycogenolysis and gluconeogenesis to insulin infusions in dogs. Diabetes, 25: 283 (1976).

6. Claus, T. H., and Pilkis, S. J.: Regulation by insulin of gluconeogenesis in isolated rat hepatocytes. Biochim. Biophys. Acta, 421: 246 (1976).

7. Denton, R. M., Randle, P. J., Bridges, B. J., Cooper, R. H., Kerbey, A. L., Pask, H. T., Severson, D. L., Stansbie, D., and Whitehouse, S.: Regulation of mammalian pyruvate dehydrogenase. Mol. Cell. Biochem., 9: 27 (1975).

8. Dershewitz, R., Vestal, B., Maclaren, N. K., and Cornblath, M.: Transient hepatomegaly and hypoglycemia: A consequence of malicious insulin administration. Amer. J. Dis. Childhood, 130: 998 (1976).

9. Exton, J. H.: Gluconeogenesis. Metabolism, 21: 945 (1972).

10. Felig, P.: The glucose-alanine cycle. Metabolism, 22: 179 (1973). 
11. Felig, P., and Wahren, J.: Influence of endogenous insulin secretion on splanchnic glucose and amino acid metabolism in man. J. Clin. Invest., 50: 1702 (1971).

12. Felig, P., Wahren, J., and Hendler, R.: Influence of physiologic hyperglucagonemia on basal and insulin-inhibited splanchnic glucose output in normal man. J. Clin. Invest., 58: 761 (1976)

13. Feliu, J. E., Hue, L., and Hers, H-G.: Hormonal control of pyruvate kinase activity and of gluconeogenesis in isolated hepatocytes. Proc. Natl. Acad Sci. USA, 73: 2762 (1976)

14. Friedmann, B., Goodman, E. H. Jr., and Weinhouse, S.: Effects of insulin and fatty acids on gluconeogenesis in the rat. J. Biol. Chem., 242: 3620 (1967).

15. Hales, C. N., and Randle, P. J.: Immunoassay of insulin with insulin-antibody precipitate. Biochem. J., 88: 137 (1963)

16. Heding, L. G.: Radioimmunological determination of pancreatic and gut glucagon in plasma. Diabetologia, 7: 1.0 (1971).

17. Hers, H. G., DeWulf, H., and Stalmans, W.: The control of glycogen metabolism in the liver. Fed. Eur. Biochem. Soc. Lett., 12: 73 (1970).

18. Hultman, E.: Rapid specific method for determination of aldosaccharides in body fluids. Nature, 183: 108 (1959).

19. Karl, I. E., Pagliara, A. S., and Kipnis, D. M.: A microfluorometric enzymatic assay for the determination of alanine and pyruvate in plasma and tissues. J. Lab. Clin. Med., 80: 434 (1972).

20. Liljenquist, J. E., Bomboy, J. D., Lewis, S. B., Sinclair-Smith, B. C., Felts, P. W., Lacy, W. W., Crofford, O. B., and Liddle, G. W.: Effects of glucagon on lipolysis and ketogenesis in normal and diabetic men. J. Clin. Invest., 53: 190 (1974).

21. Mandell, F., and Berenberg, W.: The Mauriac syndrome. Amer. J. Dis Childhood, 127: 900 (1974).

22. Marks, V.: Glucagon and lipid metabolism in man. Postgrad. Med. J., 49: $615(1973)$.

23. Mauriac, P.: Gros ventre, hépatomégalie, troubles de la croissance chez les enfants diabétiques: Traités depuis plusieurs années par l'insuline. Gaz. Hebd. Soc. Med. de Bordeaux, 26: 402 (1930).

24. McDaniel, H. G.: Acute suppression of hepatic gluconeogenesis by glucose in the intact animal. Amer. J. Physiol., 229: 1569 (1975).

25. Parrilla, R., Jimenez, M.-I., and Ayuso-Parrilla, M. S.: Cellular redistribution of metabolites during glucagon and insulin control of gluconeogenesis in the isolated perfused rat liver. Arch. Biochem. Biophys., 174: 1 (1976).

26. Parrilla, R., Jimenez, I., and Ayuso-Parrilla, M. S.: Glucagon and insulin control of gluconeogenesis in the perfused isolated rat liver: Effects on cellular metabolite distribution. Eur. J. Biochem., 56: 375 (1975).

27. Perry, T. L., Hansen, S., Tischler, B., Bunting, R., and Diamond, S. Glutamine depletion in phenylketonuria: A possible cause of mental defect New Engl. J. Med., 282: 761 (1970).

28. Ruderman, N. B., Toews, C. J., and Shafrir, E.: Role of free fatty acids in glucose homeostasis. Arch. Intern. Med., 123: 299 (1969).

29. Samols, E., Marri, G., and Marks, V.: Promotion of insulin secretion by glucagon. Lancet, ii: 415 (1965).

30. Schade, D. S., and Eaton, R. P.: Modulation of fatty acid metabolism by glucagon in man. IV. Effects of a physiologic hormone infusion in normal man. Diabetes, 25: 978 (1976).

31. Schmidt, E.: Glutamic dehydrogenase. In: H. U. Bergmeyer: Methods of Enzymatic Analysis, p. 752. (Academic Press, New York, 1965).

0031-3998/78/1205-0619\$02.00/0

Copyright (C) 1978 International Pediatric Research Foundation, Inc.
32. Sherwin, R., Wahren, J., and Felig, P.: Evanescent effects of hypo- and hyperglucagonemia on blood glucose homeostasis. Metabolism, 25: 1381 (1976).

33. Shrago, E., Young, J. W., and Lardy, H. A.: Carbohydrate supply as a regulator of rat liver phosphoenolpyruvate carboxykinase activity. Science, 158: $1572(1967)$

34. Soupart, P.: Free amino acids of blood and urine in the human. In: J. T Holden: Amino Acid Pools, p. 220 (Elsevier, Amsterdam, 1962).

35. Stanley, C. A., and Baker, L.: Hyperinsulinism in infants and children: Diagnosis and therapy. Adv. Pediat., 23: 315 (1977).

36. Tamburrano, S., Luyckx, A. S., and Lefebvre, P. J.: Studies on the hyperglycemic effect of diphenylhydantoin in normal golden hamsters. Horm. Metab. Res. Suppl., 6: 74 (1976)

37. Vidnes, J.: Gluconeogenesis in infancy and childhood. I. A method for the study of the in vivo gluconeogenesis from alanine and glycerol. Scand. J. Clin. Lab. Invest., 36: 347 (1976).

38. Vidnes, J., and Öyasæter, S.: Glucagon deficiency causing severe neonatal hypoglycemia in a patient with normal insulin secretion. Pediat. Res., 11 : 943 (1977).

39. Vidnes, J., and Sövik, O.: Gluconeogenesis in infancy and childhood. III Deficiency of the extramitochondrial form of hepatic phosphoenolpyruvate carboxykinase in a case of persistent neonatal hypoglycaemia. Acta. Pediat. Scand., 65: 307 (1976).

40. Von Glutz, G., and Walter, P.: Regulation of pyruvate carboxylation by acetyl-CoA in rat liver mitochondria. Fed. Eur. Biochem. Soc. Lett., 72. 299 (1976).

41. Weber, G., Singhal, R. L., and Srivastava, S. K.: Insulin: Suppressor of biosynthesis of hepatic gluconeogenic enzymes. Proc. Natl. Acad. Sci. U. S. A., 53: 96 (1965).

42. Weir, G. C., Turner, R. C., and Martin, D. B.: Glucagon radioimmunoassay using antiserum $30 \mathrm{~K}$ : Interference by plasma. Horm. Metab. Res., 5: 241 (1973).

43. Williamson, J. R., Jacob, A., and Scholz, R.: Energy cost of gluconeogenesis in rat liver. Metabolism, 20: 13 (1971).

44. Williamson, J. R., Kreisberg, R. A., and Felts, P. W.: Mechanism for the stimulation of gluconeogenesis by fatty acids in perfused rat liver. Proc. Nat. Acad. Sci. U. S. A., 56: 247 (1966)

45. Wimhurst, J. M., Manchester, K. L., and Harris, E. J.: The actions of insulin and glucagon on glucose metabolism and on related enzyme activities in the isolated perfused rat liver. Biochim. Biophys. Acta, 372: 72 (1974).

46. Wise, J. K., Hendler, R., and Felig, P.: Evaluation of alpha-cell function by infusion of alanine in normal, diabetic and obese subjects. New Engl. J. Med., 288: 487 (1973)

47. Wrenshall, G. A., and Hetenyi, G., Jr.: Successive measured injections of tracer as a method for determining characteristics of accumulation and turnover in higher animals with access limited to blood: Tests in hydrodynamic systems and initial observations on insulin action in dogs. Metabolism, 8: 531 (1959).

48. This work was supported by Norske Kvinners Sanitetsforening. Dr. O. Sövik aided with valuable criticism during the preparation of the manuscript

49. Requests for reprints should be addressed to: J. Vidnes, M.D., Pediatric Research Institute, Rikshospitalet, Oslo 1 (Norway).

50. Received for publication May 10, 1977.

51. Accepted for publication August 29, 1977. 